УДК 81’25+811.111
DOI 10.35433/philology.1(89).2019.124-128
Л. Л. Славова,

доктор філологічних наук, доцент

(Київський національний університет імені Тараса Шевченка slavovall16@gmail.com)

ORCID: 0000-0001-8035-1801

Н. Д. Борисенко,

кандидат філологічних наук, доцент

(Житомирський державний університет імені Івана Франка)

nat.dbor@gmail.com

ORCID: $0000-0002-2713-4864$

\title{
ЕТНОСПЕЦИФІКА КІНОПЕРЕКЛАДУ У ДЗЕРКАЛІ МІЖКУЛЬТУРНОЇ КОМУНІКАЦІЇ
}

Стаття присвячена особливостям відтворення ситуацій міжкультурної комунікації у кіноперекладі, коли персонажі є представниками різних лінгвокультур та один із мовців не достатньо володіє нормами мови спілкування. Матеріалом дослідження обрано англомовний художній фільм Термінал та його закадрові переклади украӥнською. Визначено місие кіноперекладу в системі аудіовізуального, схарактеризовано способи відтворення кінопродукції. Розглянуто лінгвокультурологічні та прагматичні особливості контамінованого мовлення в англійській мові, визначено основні способи та стратегї його відтворення в украӥнському перекладі. Виокремлено граматичні та лексичні трансформачї для відтворення англійського контамінованого мовлення українською, зокрема заміна інфінітивом особових форм дієслова, часові дієслівні форми, неправильне використання категорії роду іменників та прикметників, помилкове використання часових форм, лексичні помилки.

Ключові слова: кінопереклад, відтворення, одомашнення, відчуження, контаміноване мовлення, міжкультурна комунікація.

Постановка проблеми. На сучасному етапі розвитку вітчизняного перекладознавства все більшу увагу фахівців привертає кінематограф, який все частіше виступає об'єктом та матеріалом перекладознавчих розвідок. Останнє пояснюється швидким розвитком кіно та загальною тенденцією глобалізації, в рамках якої українські компанії намагаються полегшити доступ національному глядачеві до іноземного кіно та телепродукту. Як результат, аудіовізуальний переклад, під яким розуміють міжмовну передачу змісту кіно та телефільмів, комп’ютерних програм, телевізійних передач, випусків новин, рекламних роликів, театральних постановок та до якого відносять більш ніж десять типів перекладу [1: 353], потребує детального вивчення і класифікації. Наразі українські перекладознавці визначають місце кіноперекладу в типології аудіовізуального [2], виокремлюють прецедентну асиметрію як перекладацький прийом під час перекладу кінодискурсу [3], досліджують особливості відтворення комічного засобами цільової мови [1], встановлюють одиниці перекладу окремих жанрів кіно [4], розглядають кінодискурс як об'єкт навчання перекладачів [5]. Проте, не зважаючи на достатню кількість розвідок у царині кіноперекладу практика відтворення кінодискурсу засобами цільової мови не отримала необхідного теоретичного осмислення у вітчизняній науці і потребує подальших досліджень.

Хоча існують певні відмінності у способах відтворення кінопродукції у різних країнах, в цільовій культурі останні зводяться до субтитрування та переозвучування у вигляді закадрового перекладу та дубляжу [1: 353]. В українській традиції при перекладі англійськомовного кінодискурсу перевага надається двом останнім способам. Закадровий переклад (voice-over) довгий час не отримував достатньої уваги у західноєвропейській теорії перекладу, що пов'язано із труднощами визначення терміну, який розуміється неоднозначно різними дослідниками, порівняно нещодавнім виникненням теорії аудіовізуального перекладу та використанням закадрового перекладу у західних країнах переважно під час перекладу документальних фільмів [6: 211-212]. На противагу цьому, довгий час в українському кінематографі він був панівним під час перекладу художніх фільмів [1: 354], оскільки виконується швидше ніж дубляж, $є$ технічно менш складним, дешевшим, не потребує синхронізації тексту перекладу 3 артикуляцією акторів [7: 442]. Дубляж, який потребує більших фінансових та технічних затрат, повністю замінює вербальну складову кінодискурсу, при цьому відбувається синхронізація артикуляції акторів та звукового ряду для того, щоб створювати враження, що актори на екрані говорять цільовою мовою, та приховати факт перекладу. Останнє неможливо зробити під час закадрового перекладу, коли звуковий ряд на цільовій мові накладається на приглушений текст оригіналу. Сьогодні українські кінокомпанії пропонують як дубляж, так і закадровий переклад англомовних кінофільмів, створюючи широке поле для досліджень в галузі лінгвокультурології і перекладу та порівняння впливу двох видів відтворення іншомовного кінодискурсу на глядача цільової лінгвокультури [7: 442-444]. 
У кіноперекладі оригіналом є текст, який передається за допомогою аудіо- та візуального каналів (кіно театральний та телевізійний переклад) або письмового, аудіо- та візуального каналів (мультимедійний переклад) [2].

Мета розвідки полягає у виявленні лінгвокультурологічних та прагматичних особливостей відтворення міжкультурної комунікації англомовних кінофільмів українською мовою.

Матеріалом дослідження обрано випущений у 2004 році англомовний художній фільм Термінал (Тhе Terminal) режисера та продюсера Стівена Спілберга [8], що належить до жанру трагікомедії, та його переклади українською, виконані телеканалами Інтер [9] та Новим каналом [9]. Вибірку прикладів було сформовано у ході зіставного аналізу реплік персонажів вихідною та цільовою мовами.

Виклад основного матеріалу дослідження. Особливий інтерес у кіноперекладі представляють ситуації, учасниками яких $\epsilon$ персонажі, що належать до різних лінгвокультурних спільнот та демонструють відмінності у вербальній та невербальній поведінці, спілкуючись мовою, яка для одного 3 комунікантів $\epsilon$ іноземною та якою останній володіє не в достатній мірі. У такому випадку виникає необхідність відтворення у перекладі контамінованого мовлення, під яким дослідники розуміють висловлення іноземця, який використовує спотворені мовні форми, елементи розмовного стилю та прості граматичні форми, оскільки недостатньо володіє нормами мови. Відтворення таких форм у перекладі має на меті відобразити особливості мовлення особи та відтворити прагматичний потенціал вихідного тексту засобами цільової мови.

У ситуації спілкування робітників аеропорту та Віктора Наворські, який є громадянином розташованої у Східній Свропі неіснуючої країни Кракожія та рідною мовою якого $\epsilon$ одна із слов'янських мов, має місце культурне непорозуміння, оскільки Віктор на початку свого перебування у терміналі майже не володіє англійською мовою, а пізніше робить помилки, притаманні іноземцям, які не в достатній мірі володіють мовними компетенціями.

До найбільш типових способів презентації контамінованого мовлення в аналізованих перекладах відносимо використання інфінітива замість особової форми дієслова. Наприклад,

My friend drive the food [8].

В українському перекладі відповідником є вживання неозначеної форми дієслова:

Мій друг возити всяку їжу [9].

Помилки, пов'язані із відсутністю допоміжного дієслова у загальних питаннях:

Officer Torres, you like the films? [8], відтворюються в українському перекладі за допомогою неозначеної форми дієслова:

Офіцер Торес, вам подобатися фільми, кіно? [9].

Для створення мовної характеристики персонажа, який недостатньо володіє мовою, в українській мові використовують помилки, пов'язані із використанням граматичних категорій роду та відмінку. Наприклад, вихідна фраза:

She say one thing. Very important [8] містить лише одну граматичну помилку у використанні особової форми дієслова у формі третьої особи однини у теперішньому неозначеному часі. В обох перекладах для іiї відтворення використано неозначену форму дієслова: Вона казати одна річ. Дуже важливо [8]. Вона сказати один річ. Дуже важливий [9]. Проте відмінність полягає у використанні доконаного стану у другому випадку, що додатково сигналізує про те, що правильно оформлена фраза в українській мові вживається саме у доконаному стані. Крім того, в обох перекладах форма іменника, який в англійській мові не має категорій відмінка та граматичного роду, свідчить про те, що його використано у називному відмінку замість знахідного. У другому перекладі іменник віднесено до чоловічного роду, на що вказує прикметник один. Вищезазначені граматичні помилки мають підсилити враження глядача про недостатній рівень володіння головним героєм мовою спілкування.

Порівняння двох українських перекладів кінострічки показує, що вибір способу відтворення контамінованого мовлення залежить від перекладача. Наприклад, у ситуації спілкування робітника льотовища та головного героя, останній, який вже певним чином володіє англійською мовою, робить граматичні помилки:

- You help me to win her heart, and you'll never go hungry again.

- I do this [8].

Як бачимо $з$ прикладу у мовленнєвому акті промісиву (I do this), який в англійській мові реалізує дієслово у формі майбутнього часу, використано теперішній час, що вказує на недостатнє володіння граматичними та прагматичними нормами мови, проте не перешкоджає порозумінню.

У перекладі помилку відтворено у версії телеканалу Інтер:

Я це робити [9], де використано інфінітив замість дієслова у формі майбутнього часу та проігноровано у варіанті Нового каналу:

Я це зроблю [10], у якому використано мовленнєвий акт промісиву.

В окремих випадках у перекладі не відтворюються граматичні помилки. Так, у репліці головного героя відсутня частка to перед інфінітивом What do you want know? [8], яка не відображена в українських 
перекладах. Натомість переклад каналу Інтер звучить абсолютно нейтрально та не дає уявлення про рівень володіння мовою: Що ти хочеш знати? [9]. У перекладі Нового каналу питання хоча і $\epsilon$ граматично правильним не зовсім відповідає ситуації, а отже сигналізує про недостатнє володіння героєм нормами мови: Що тобі треба? [10] з імплікатурою Що ти хочеш від мене?

Лексичні помилки, які мають місце у мовленні головного героя, пов'язані із схожістю звукової оболонки англійських слів та призводять до гумористичного ефекту, що не завжди може бути відтворене у перекладі. Так, лексему cheat - to be sexually unfaithful [11] мовець сплутав з багатозначним словом chit - a pert young woman, a short letter or note [11], яке як дієслово використовується лише в британському варіанті англійської мови: cause (a potato) to sprout by placing it in a cool light place [12]:

- What happened?

- He chit.

- What?

- He chit.

- Eat shit?

- He chit. He chit. He chit.

- Try to repeat exactly what she said.

- He chit. She catch him. So...

- Ohh! He cheats! [8].

Лише додаткове пояснення (He chit. She catch him) робить смисл зрозумілим слухачеві.

В українському перекладі каналу Інтер знаходимо вдалу спробу відтворити звукову подібність лексем чхав та брехав:

Енріке. А щзо сталося?

Віктор. Він чхав.

Енріке. Що?

Віктор. Чхав.

Енріке. Чхав?

Віктор. Чхав. Чхав. Чхав.

Енріке. Гаразд. Не поспішаючи. Повтори їі слова.

Віктор. Він чхав. Вона ловити його.

Енріке. Він брехав [9].

Крім того, в переносному значенні лексема чхати - не визнавати кого-, щуо-небудь, лишати поза увагою кого-, що-небудь, висловлювати байдужість, зневагу до когось, чогось [13: 392] актуалізує сему 'негативне відношення до людини' і може бути використана для опису відносин між людьми. Проте помилка стає зрозумілою лише після роз'яснення (Вона ловити його).

Отже, кінопереклад, як і переклад загалом - це вид міжкультурної та міжмовної взаємодії. Дослідження дозволяє зробити висновок, що в ситуації міжкультурної комунікації іноземці, рідною мовою яких є слов'янські, роблять помилки, які свідчать про їх недостатнє володіння англійською мовою. Граматичні помилки включають використання інфінітива замість особової форми дієслова, опущення допоміжного дієслова, лексичні помилки здебільшого пов'язані із звуковою подібністю слів. Обидві групи помилок відтворюються у перекладі для збереження прагматичного потенціалу вихідного кінотексту засобами цільової мови.

Подальші перспективи дослідження вбачаються нам у створенні типології стратегій кіноперекладу 3 урахуванням взаємодії автора та кінореципієнта за допомогою засобів кіномови.

\section{СПИСОК ВИКОРИСТАНИХ ДЖЕРЕЛ ТА ЛІТЕРАТУРИ}

1. Словник української мови : в 11 т. / ред. кол. : І. К. Білодід (гол. ред.) та ін. - Київ : Вид-во "Наукова думка", 1980. - Т. 11: Х-Ь. - 700 с.

2. Мельник А. П. Кінопереклад як особливий тип аудіовізуального перекладу / А. П. Мельник // Наукові записки Національного університету "Острозька академія". Серія : Філологічна. - 2015. - Вип. 58. - С. 110 112.

3. Шукало I. М. Специфіка перекладу комічного у кінодискурсі/ I. М. Шукало // Наукові записки [Ніжинського державного університету ім. Миколи Гоголя]. Серія : Філологічні науки. - 2013. - Кн. 3. C. $171-173$.

4. Конкульовський В. До визначення одиниці перекладу кінокомедій / В. Конкульовський // Наукові записки. Серія : Філологічні науки (мовознавство). - Кіровоград : РВВ КДПУ ім. В. Винниченка. - Вип. 104. - Ч. 2012. - C. 263-266.

5. Гридасова О. І. Кінодискурс як об’єкт навчання кіноперекладу / О. І. Грідасова // Вісник ЖДУ. Вип. 2 (74). - C. 102-107.

6. Borodo M. Eliana Franco, Anna Matamala and Pirar Orero, Voice-over Translation : An Overview. 2010, Bern ; Berlin; Bruxelles : Peter Lang, pp. 248 / Michal Borodo // Linguistics Applied vol. 4 (2011). - Pp. 211-215.

7. Cintas J. D. Voiceover and Dubbing / Jorge Diaz Cintas \& Pilar Orero // Handbook of Translation Studies v. 1. Ed. by yeves Gambier, Luc van Doorslaer Amsterdam / Philadelphia, 2010. - P. 441-445. 
8. The Terminal Script - Dialogue Transcript. - URL : http://www.script-o-rama.com/movie_scripts/t/terminal-scripttranscript-tom-hanks.html (дата звернення : 25.04.2019).

9. Термінал. Закадровий переклад телеканалу Iнтер. - URL : https://kinoukr.com/1789-terminal.html (дата звернення: 25.04.2019).

10. Термінал. Закадровий переклад Нового каналу. - URL : http://moviestape.net/katalog_filmiv/komedija/304terminal.html (дата звернення: 25.04.2019).

11. Dictionary by Merriam-Webster. - URL : https://www.merriam-webster.com (дата звернення: 25.04.2019).

12. Oxford Dictionaries : English Dictionary, Thesaurus, \& grammar help. - URL : https://en.oxforddictionaries.com (дата звернення : 25.04.2019).

13. Савко М. В. Аудиовизуальній перевод в Беларуси / М. В. Савко // Мова і культура. - 2011. - Вип. 14, т. 6. C. 353-357.

14. Ярова Л. О. Прецедентна асиметрія в аудіовізуальному перекладі / Лариса Олегівна Ярова // Наукові записки ЦДПУ. Серія: Філологічні науки = Research Bulletin. Series: Philological Sciences / ред. кол. : О. А. Семенюк [та ін.]. - Кропивницький : КОД, 2019. - Вип. 175. - С. 738-743.

\section{REFERENCES TRANSLATED AND TRANSLITERATED}

1. Slovnyk ukrains'koi movy [Dictionary of Ukrainian] : v 11 t. / red. kol. : I. K. Bilodid (gol. red.) ta in. - Kyiv : Vyd-vo "Naukova dumka", 1980. - T. 11.-700 s.

2. Melnyk A. P. Kinopereklad yak osoblyvyi typ audiovizual'noho perekladu [Translation of Films as Peculiar Type of Audio-Visual Translation] / A. P. Melnyk // Naukovi zapysky Natsional'noho universytetu "Ostrozka akademiia". Seriia : Filolohichna [Naukma Research Papers. Linguistics]. - 2015. - Vyp. 58. - S. 110-112.

3. Shukalo I. M. Spetsyfika perekladu komichnoho u kinodyskursi [Specificity of Translating Comical in CinemaDiscourse] / I. M. Shukalo // Naukovi zapysky [Nizhynskoho derzhavnoho universytetu im. Mykoly Hoholia]. Seriia : Filolohichni nauky [Scientific Notes. Series Philology]. -2013. - Kn. 3. - S. 171-173.

4. Konkulovskyi V. Do vyznachennia odynytsi perekladu kinokomedii [To Defining the Unit of Translation in FilmTranslation] / V. Konkulovskyi // Naukovi zapysky. Seriia : Filolohichni nauky (movoznavstvo) [Research Bulletin. Series: Philological Sciences (Linguistics)]. - Kirovohrad : RVV KDPU im. V. Vynnychenka. Vyp. 104. - Ch. - 2012. - S. 263-266.

5. Grydasova O. I. Kinodyskurs yak obiekt navchannia kinoperekladu [Film-Discourse as an Object of FilmTranslation Teaching] // Visnyk ZhDU [Zhytomyr Ivan Franko State University Journal]. - Vyp. 2 (74). - S. 102107.

6. Borodo M. Eliana Franco, Anna Matamala and Pirar Orero, Voice-over Translation : An Overview. 2010, Bern ; Berlin; Bruxelles : Peter Lang, pp. 248 / Michal Borodo // Linguistics Applied vol. 4 (2011). - Pp. 211-215.

7. Cintas J. D. Voiceover and Dubbing / Jorge Diaz Cintas \& Pilar Orero // Handbook of Translation Studies v. 1. Ed. by yeves Gambier, Luc van Doorslaer Amsterdam / Philadelphia, 2010. - P. 441-445.

8. The Terminal Script - Dialogue Transcript. - URL : http://www.script-o-rama.com/movie_scripts/t/terminal-scripttranscript-tom-hanks.html (дата звернення : 25.04.2019).

9. Terminal [The Terminal]. Zakadrovyi pereklad telekanalu Inter [Voice-over Traslation of Inter Channel]. - URL : https://kinoukr.com/1789-terminal.html (data zvernennia: 25.04.2019).

10. Terminal [The Terminal]. Zakadrovyi pereklad Novoho kanalu [Voice-over Translation of Novyi Channel]. URL : http://moviestape.net/katalog_filmiv/komedija/304-terminal.html (data zvernennia : 25.04.2019).

11. Dictionary by Merriam-Webster. - URL : https://www.merriam-webster.com (data zvernennia: 25.04.2019).

12. Oxford Dictionaries : English Dictionary, Thesaurus, \& grammar help. - URL : https://en.oxforddictionaries.com (дата звернення : 25.04.2019).

13. Savko M. V. Audyovyzualnii perevod v Belarusy [Audio-Visual Translation in Belarus] / M. V. Savko // Mova i kul'tura [Language and Culture]. - 2011. - Vyp. 14, t. 6. - S. 353-357.

14. Yarova L. O. Pretsedentna asymetriia v audiovizual'nomu perekladi [The Precedent Asymmetry In Audiovisual Translation] / Larysa Olehivna Yarova // Naukovi zapysky TsDPU. Seriia: Filolohichni nauky [Research Bulletin. Series: Philological Sciences] / red. kol.: O. A. Semeniuk [ta in.]. - Kropyvnytskyi : KOD, 2019. - Vyp. 175. S. $738-743$.

\section{Славова Л. Л., Борисенко Н. Д. Етноспецифика киноперевода в зеркале межкультурной коммуникации.}

Статья посвящена особенностям воспроизведения ситуаций межкультурной коммуникации в кинопереводе, когда персонажи являются представителями разных лингвокультур и один из говорящцих недостаточно владеет нормами языка общения. Материалом исследования избран англоязычный художественный фильм Терминал и его закадровые переводы на украинский. Определено место киноперевода в системе аудиовизуального, охарактеризованы способы воспроизведения кинопродукции.

Рассмотрень лингвокультурологические и прагматические особенности контаминированной речи 8 английском языке, определены основные способы и стратегии его воспроизведения в украинском переводе. Выделены грамматические и лексические трансформации для воспроизведения английской контаминированной речи на украинском, в частности замена инфинитивом личных форм глагола, временные глагольные формы, неправильное использование категории рода существительных и прилагательных, ошибочное использование временных форм, лексические очибки. 
Ключевые слова: киноперевод, воспроизведение, одомашнивания, отчуждение, контаминированная речь, межкультурная коммуникация.

\section{Slavova L. L., Borysenko N. D. Ethnospecific Features of Film Translation in the Mirror of Intercultural Communication.}

The article deals with the specific features of intercultural communication situations reproduction in film translation, when characters are representatives of different linguocultures and one of the speakers is not sufficiently fluent in the norms of the language of communication. The English feature film Terminal and its offscreen translations into Ukrainian were chosen as material of the research. The place of film translation in the audiovisual one has been determined, the ways of reproduction of film production have been characterized. The maim types of audiovisual translation are dubbing, subtitling and voice-over. The difficulty of audiovisual translation is due to the presence of both audio and video signs. In film translation, the original text is transmitted through audio and visual channels or written, audio and visual channels. The latter is also called multimedia translation. Linguoculturological and pragmatic features of contaminated speech in the English language are considered, the main methods and strategies of its reproduction in the Ukrainian translation are defined. Characters belonging to different linguocultural communities show differences in verbal and non-verbal behavior. Since the language of communication for one of the communicants is foreign, so he does not know it sufficiently well. In such a case, there is a need to reproduce the translation of contaminated speech. The latter is understood as the speech of a foreigner who uses distorted language forms, elements of colloquial style and simple grammatical forms, because he does not have sufficient language skills. The reproduction of such forms

in translation is intended to reflect the characteristics of the person's speech and recreate the pragmatic potential of the source text by means of the target language. The grammatical and lexical transformations to reproduce English contaminated speech in Ukrainian are highlighted, in particular, the replacement of personal verb forms by the infinitive, tense verb forms, the incorrect use of the category of nouns and adjectives, the erroneous use of tense forms, lexical errors. Film translation is a kind of intercultural and interlingual interaction. The study leads to the conclusion that in a situation of intercultural communication, foreigners, whose native language is Slavic, make mistakes indicating their lack of English proficiency. All groups of errors are reproduced in translation to preserve the pragmatic potential of the source film text by means of the target language.

Key words: film translation, reproduction, domestication, foreignization, contaminated speech, intercultural communication. 